\title{
原琵論文
}

\section{複数化学物質の動態を考慮した 流域水生態環境評価モデルの構築}

和佐 守紜 1) 川口智哉 2) 小尻利治 3 ) 東海 明宏 4$)$

1) 日本工営株式会社

（テ102-8539＼cjkstart東京都千代田区趋町5-4）

2)株式会社日水コン

（１63-1122 東京都新宿区西新宿6-22-1 新宿スクエアタワー）

3) 京都大学防災研究所水資源環境研究センター

( ₹611-0011 宇治市五ヶ庄)

4)独立行政法人産業技術総合研究所 化学物質リスク管理研究センター （テ305-8569 つくば市小野川16-1）

本研究では, 分布型流出モデルによって求めた時空間的な水量分布を利用し，環境中における毒性化学物質濃度 の動態推定と生態系への影響評価モデルを構築する。対象流域として琵琶湖・淀川流域を選び，界面活性剂として 使用されるノニルフェノールとLASについて詳細な水質モデルを用いて濃度分布を推定した後, 複数の毒性化学物 質への外捙を行う.さらに, 求めた複数の化学物質濃度を入力として, PBPKモデルを用い評価対象とする魚類への 蓄積濃度を計算する。最後に, 求めた蓄積化学物質濃度を用い魚類に対するリスク評価を行う.

キーワード：分布型流出モデル, 流域水環境, 化学物質, PBPK

\section{I 。緒言}

現代社会において化学物質は必要不可欠なもので あり, 日常的に数万種もの化学物質が生成, 利用さ れ，その一部は環境中に排出されている. 現在に至 るまで，その有用性とともに危険性も認識され，近 年では環境ホルモン問題に見られるように生態系に 対する影響も認識されるようになって来た(松井他 ${ }^{1)}$, 2002). 水域に打いても，様々な排出源から常に化 学物質が排出されており, 生態系に対して何らかの 影響を及ぼしている可能性がある。特に, 自然流量 が少なく, 流量の大半を下水が占めるような河川で は生態系への影響が懸念されており, 今後重点的に 研究していく必要がある (Brooks, et al. ${ }^{2)}$, 2006).

一方，近年の地理情報システム（Geographic Information System）の発達により, 地理情報, 気象 情報, 統計情報等の詳細な空間分布を入手すること が容易になってきた。東海らは, 河川流量の時空間 分布を把握することのできる分布型流出モデルをも とに, 魚類個体数に与える影響を指標とし, 環境ホ
ルモンの環境中での動態, 及び魚類の体内での動態 を考慮した流域環境評価モデル（Hydro-BEAM: Hydrological river Basin Environment Assessment Model）を提案した（東海他 ${ }^{3)}$ ，2002）。また，1999 年には「特定化学物質の環境への排出量の把握等及 び管理の改善の促進に関する法律」（通称PRTR法: Pollutant Release and Transfer Register) が制定され, PRTR法で指定されている物質については, きめ細 かな排出量情報を得ることが可能となってきた。

こうした背景のもと, 本研究では, Hydro-BEAM を拡張し, 複数の化学物質について物理的性質 (水 溶性, 拡散移動, 生分解性等) を考慮した上で魚類 に与える影響を評価指標とした流域水生態環境評価 モデルを構築し, 対象流域に扔ける魚類への化学物 質リスク評価を試みる。 


\section{II．流域環境評価モデルの構成}

\section{1. 流域環境評価モデルの概要}

流域環境評価モデル（Hydro-BEAM）は大きく分 けて, 熱収支モデル, 流出モデル, 水質モデル, 毒 性化学物質動態モデル，生態系評価モデルの5つの モデルからなる。まず，地理データ，気象データな どから熱収支モデルを用いて地表面の熱収支を求め る. 求めた熱収支から蒸発散量を推定した上で雨量 などのデー夕を用い，分布型流出モデルを用いて地 表と地下の水分移動量を求める. 水分移動量や排出 量デー夕などを用いて，毒性化学物質の流域での動 態を推定し, 化学物質濃度を用いて, 生態系を中心 とする水環境への影響評価を行う (図一1参照).

本研究では, 従来の流域環境評価モデルに対して, 任意の化学物質の物理的性質を考慮すべく, 水質モ デルを追加し, ケーススタディーを通して毒性化学 物質動態モデルと生態系評価モデルの精緻化を図る.

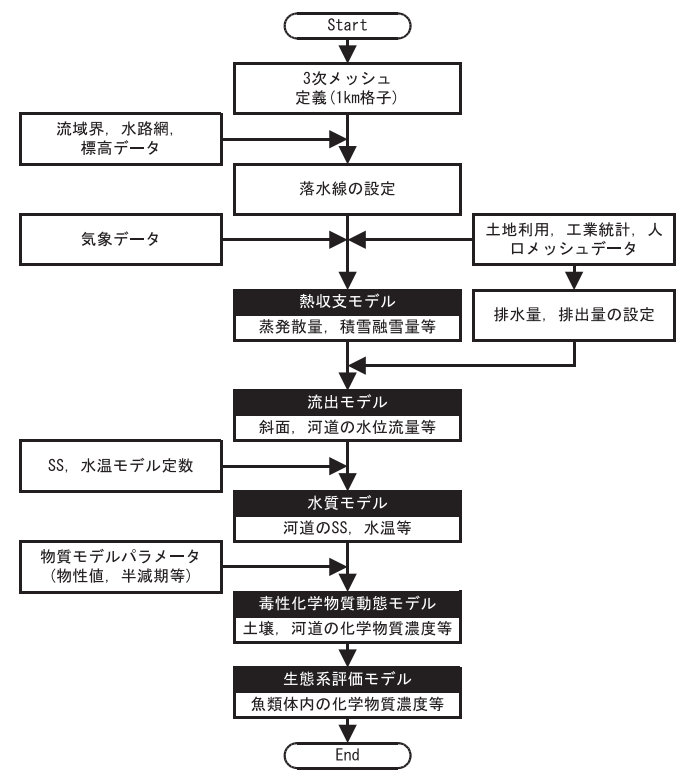

図 -1 流域水環境の評価手順

Fig.1 Evaluation process of river basin environment.

\section{2. 水量モデルの定式化}

1）地表面およびA層

畑・山林・市街地では，地表面およびA層に中間 流出を考慮したkinematic wave法を用いる。

$$
\frac{\partial h_{A l}}{\partial t}+\frac{\partial q_{A l}}{\partial x}=r f_{A l}
$$

$$
\begin{aligned}
& \Psi_{A l}=\left(\begin{array}{c}
\alpha\left(h_{A l}-d_{A}\right)^{m}+a h_{A l} \\
a h_{A l}
\end{array}\right), \\
& w h e m\left(\begin{array}{l}
h_{A r} \geq d_{A} \\
h_{A I}<d_{A}
\end{array}\right) \\
& d_{A}=\lambda_{A} D_{A} \\
& \alpha=\frac{\sqrt{\sin \theta}}{n}, \text { (Manning type) } \\
& \left.a=\frac{k \sin \theta}{\lambda_{A}}, \quad \text { (Darcy type }\right) \\
& m_{b}=\frac{5}{3}
\end{aligned}
$$

ここに, $h$ : 水深 $(\mathrm{m}), q$ : 単位幅流量 $\left(\mathrm{m}^{2} \mathrm{~s}^{-1}\right), r$ : 降雨 強度 $\left(\mathrm{m} \mathrm{s}^{-1}\right), f_{A}$ : 直接流出率, $\sin \theta$ : 斜面勾配, $n$ : 斜 面の等価粗度 $\left(\mathrm{m}^{-1 / 3} \mathrm{~s}\right), k$ : 透水係数 $\left(\mathrm{m} \mathrm{s}^{-1}\right), \lambda$ : 空隙 率, $D$ : 層厚 $(\mathrm{m}), d$ : 飽和水深 $(\mathrm{m}), l$ : 土地利用(ここでは, 畑, 山林, 市街地), $A$ : A層を表す添元字, $m_{b}$ : Manning 則定数，とする．水田には，期別毎に目標維 持水深を変化させることのできる複合タンクモデル を用いる。

\section{2) B層}

B層では，線形貯留法を適用する。

$$
\begin{aligned}
& \frac{d h_{B}}{d t}=I_{B}-q_{B} \\
& q_{B}=q_{h B}+q_{v B} \\
& I_{B}=r\left(1-\bar{f}_{A l}\right)+u_{C} \\
& \bar{f}_{A l}=\frac{\sum_{l} f_{A l} A_{l}}{\sum_{l} A_{l}} \\
& q_{h B}=k_{h B} \max \left(h_{B}-Z_{B}, 0\right) \\
& q_{v B}=k_{v B} h_{B} \\
& Z_{\Delta}=D_{a}\left(\lambda_{s}-\lambda_{v}\right) \\
& u_{B}=\left(\begin{array}{c}
h_{B}-d_{B} \\
0
\end{array}\right), \quad \text { when }\left(\begin{array}{l}
h_{B} \geq d_{B} \\
h_{B}<d_{B}
\end{array}\right) \\
& d_{B}=\lambda_{B} D_{B}
\end{aligned}
$$

ここに, $h$ : 水深 $(\mathrm{m}), I$ : 流入高 $\left(\mathrm{m} \mathrm{s}^{-1}\right), q$ : 流出高 $\left(\mathrm{m} \mathrm{s}^{-1}\right), u$ : 復帰高 $\left(\mathrm{m} \mathrm{s}^{-1}\right), k_{h}$ および $k_{v}$ : 現地土壤の水 平㧍よび鉛直透水定数 $\left(\mathrm{s}^{-1}\right), \lambda$ : 空隙率, $D$ : 層厚 
$(\mathrm{m}), d$ : 飽和水深 $(\mathrm{m}), B$ : B 層を表す添字, $\lambda_{w}$ : 流出に 寄与する空隙率, である. 水深高 $h$ が飽和水深量 $d$ を超 過した場合, その溢水量 $u$ は上層へ復帰するものとする。

$\mathrm{C}$ 層，D層もB層と同じく線形貯留法を用い，河道 ではRegime公式を用い任意地点の横断面諸元を設 定してkinematic wave法を適用する。

\section{SSモデルの定式化}

SS（Suspended Solids）は水中に浮遊する小粒状 物質（孔径 $1 \mu \mathrm{m}-2 \mathrm{~mm}$ ) の総称であり, 粘土鉱物に 由来する微粒子や，動植物プランクトンおよびその 死骸, 下水·工場排水に由来する有機物や金属の沈 殿が含まれる (宗宮 $\left.{ }^{4}, 1990\right)$ ，水中では，親水性の 高い化学物質は主に水に溶け, 脂溶性の高い化学物 質は主にSSに吸着される.SSに吸着された化学物質 は河床へ沈降するか下流へ運搬される。このため, 脂溶性の高い化学物質を解析する際にはSSの動態を 考慮する必要がある。

河川水と河川浮泥層との物質移動に関しては，河 川に流入するSS成分が沈降した浮泥部分が支配的 であると仮定し, 河川浮泥層の厚さはSSの挙動よ り決定できるとして, 以下のようにモデルを構築す る. な抢, 河道からの取水, 下水処理場からの点源 排水は合流点において考慮する。河道では移流拡散 過程に加え, 沈降や再浮上といった物理的な挙動を 考慮すると次式を得る。

$$
\begin{aligned}
& \frac{\partial}{\partial t}\left(A, C_{*}\right)+\frac{\partial}{\partial x}\left(A, U, C_{-}\right) \\
& =\frac{\partial}{\partial x}\left(A, D, \frac{\partial C_{n}}{\partial x}\right)-W \frac{A}{H}+G \frac{A}{R}+f_{A} \\
& \frac{d F_{F}}{d t}=W \frac{A}{H}-G \frac{A}{R}
\end{aligned}
$$

$$
\text { D. }-5.93 H_{\cdot} \cdot u^{*}
$$

ここに, $A_{r}$ : 流水断面積 $\left(\mathrm{m}^{2}\right), C_{S S}$ : $\mathrm{SS}$ の濃度 $\left(\mathrm{g} \mathrm{m}^{-3}\right)$, $U_{r}$ : 断面平均流速 $\left(\mathrm{m} \mathrm{s}^{-1}\right), D_{r}$ : 拡散係数 $\left(\mathrm{m}^{2} \mathrm{~s}^{-1}\right), W$ : $\mathrm{SS}$ の沈降フラックス $\left(\mathrm{g} \mathrm{m}^{-2} \mathrm{~s}^{-1}\right), H_{r}$ : 平均水深 $(\mathrm{m}), G$ : $\mathrm{SS}$ の再浮上フラックス $\left(\mathrm{g} \mathrm{m}^{-2} \mathrm{~s}^{-1}\right), R$ : 径深 $(\mathrm{m}), f_{S S}$ : 河 道へのSS流入負荷量 $\left(\mathrm{g} \mathrm{m}^{-1} \mathrm{~s}^{-1}\right), F_{S S}$ : 河川浮泥のSS堆 積量 $\left(\mathrm{g} \mathrm{m}^{-1}\right), u^{*}$ : 摩擦速度 $\left(\mathrm{m} \mathrm{s}^{-1}\right)$, である.ただ, 河 川浮泥厚は

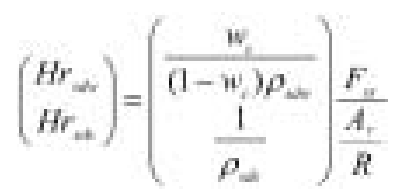

で示される.ここに, $H r_{s d w}$ : 浮泥液相の厚み $(\mathrm{m}), H r_{s d s}$ : 浮泥固相の厚み $(\mathrm{m}), w_{c}$ : 河川浮泥の含水率, $\rho_{s d w}$ : 媒体密度 $\left(\mathrm{g} \mathrm{m}^{-3}\right), \rho_{\text {sds }}$ : SSS粒子の密度 $\left(\mathrm{g} \mathrm{m}^{-3}\right)$, であ る. 水温も考慮するが, ここでは省略する.

\section{III．流域水生態環境評価モデル}

\section{1. 毒性化学物質動態モデル}

毒性化学物質の移流拡散過程は図一2のように構 成され，A-D層，水路，河道に分けて求められる. 排出物質だけでなく，分解代謝物を含む2物質の場 合の微生物による生分解過程は次のようになる。

$$
\begin{aligned}
& \frac{d C^{4}}{d t}=-\left(\theta^{12} K^{L 4}+\theta^{12 \pi} K^{1 z}\right) C^{\prime} \text {. } \\
& \frac{d C^{4}}{d t}=\theta^{2} K^{12} C^{1}-K^{2 \theta} C^{2} \text {. } \\
& K=1.047^{k-2} d k
\end{aligned}
$$

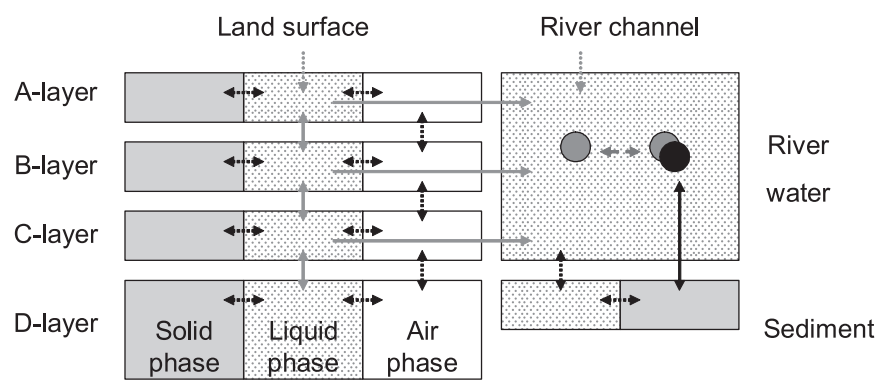

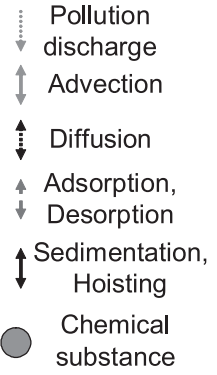

Suspended solid

図-2 メッシュ内における毒性化学物質の動態

Fig.2 Toxic-chemicals dynamics in mesh. 
ここに, $C$ : 毒性化学物質濃度 $\left(\mathrm{mg} \mathrm{m}^{-3}\right), C^{l}: 1$ は排 出物質を表す添字, $C^{2}: 2$ は分解代謝物を表す添

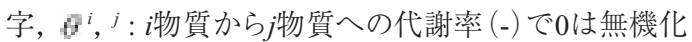
後の物質を表す添字, $K$ : 分解速度定数 $\left(\mathrm{s}^{-1}\right), d k$ : $20{ }^{\circ} \mathrm{C}$ での分解速度定数 $\left(\mathrm{s}^{-1}\right), \theta_{b}$ : 媒体の温度 $\left({ }^{\circ} \mathrm{C}\right)$, を表す。

\section{1）土壤における物質動態のモデル化}

土壤中では，土粒子の間隙に水と空気が混在して いるが, 計算のため模式的に気相・液相・固相に分 けて考える。また，空隙率から気相・液相と固相を 分け，気相と液相は飽和水深に対する水深の割合を 液相，残りを気相として分ける。土畩層の気相間 （ia-ja）での分子拡散による物質移動は，式（21） のように表される。

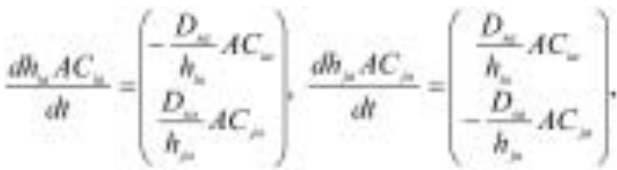

$$
\begin{aligned}
& \text { when }\left(\begin{array}{l}
C_{m} \geq C_{p} \\
C_{w}<C_{p}
\end{array}\right)
\end{aligned}
$$

また，土壤層内での気相－液相間（ia-iw）の分子拡 散による物質移動は，以下のように表される。

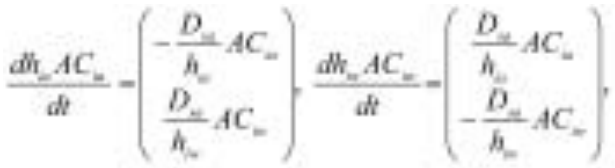

$$
\begin{aligned}
& \text { wher }\left(\begin{array}{l}
C_{\nu} \geq C_{\nu} \\
C_{u}<C_{-}
\end{array}\right)
\end{aligned}
$$

一方，土壤層内での液相一固相間（iw-is）の移動速度 定数にて定義される物質移動は，以下のようになる.

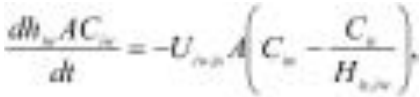

$$
\begin{aligned}
& \frac{d h_{n} A C_{m}}{d t}=U_{m-n} A\left(C_{-}-\frac{C_{u}}{H_{m}}\right)
\end{aligned}
$$

ここに, $D_{s a}$ : 土壤気相中に扔ける分子拡散係数 $\left(\mathrm{m}^{2} \mathrm{~s}^{-1}\right), U$ : 移動速度定数 $\left(\mathrm{m} \mathrm{s}^{-1}\right), H$ : 分配平衡定 数, $i, j:$ 土層, $a, w, s$ : 固相, 液相, 固相を表す添え字, である。

土壤層の気相・液相・固相での化学物質の収支式 は，以下のようになる。すなわち，
$\mathrm{A}$ 層気相（Aa）：

$$
\begin{aligned}
& \frac{d h_{w} A C_{A}}{d t}=F_{a a}+F_{a w}-K_{A a} h_{A a} A C_{A a} \text {, } \\
& F_{a a}=\left(\begin{array}{l}
-\frac{D_{m}}{h_{i+}} A C_{s} \\
\frac{D_{a}}{h_{m}} A C_{L}
\end{array}\right) \text {, when }\left(\begin{array}{l}
C_{A a} \geq C_{B a} \\
C_{A a}<C_{B a}
\end{array}\right)
\end{aligned}
$$

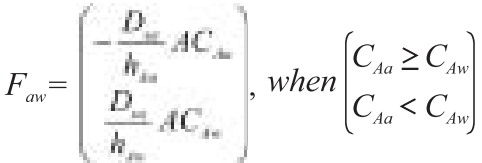

$\mathrm{A}$ 層液相（Aw）：

$$
\begin{aligned}
& \frac{d h_{n} A C_{A N}}{d t}=-n\left(1-\bar{f}_{A}\right) A C_{+}-\bar{q}_{A} C_{s} \\
& +w_{3} A C_{2}+x_{-}^{*}-F_{-}
\end{aligned}
$$

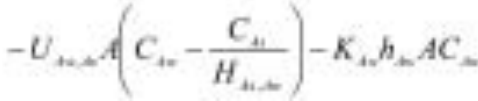

A層固相（As）：

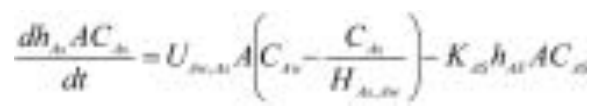

ここに, $x_{m n p}$ : 地先排出量 (農薬) $\left(\mathrm{mg} \mathrm{s}^{-1}\right)$, ini : 排出 物質を表す添字（代謝後の物質は含まない），であ る， B層， C層， $\mathrm{D}$ 層はA層と同様に定式化されるの で，ここでは省略する。

\section{2）水路における物質動態のモデル化}

水路では, 地先排水が河川に流机込むまでの流達 過程を点源排水と堆積掃流過程に分けてモデル化す る。点源排水の質量配分率は溶存態と懸濁態とは平 衡であると仮定し, 物質の物性值を反映すべくフガ シティーモデル（レベル1）に基づき設定する．晴 天時に流出しない残存負荷量（沈降による残存）は 出水時に掃流されるとし，次のように定式化する。

$$
\begin{aligned}
& f_{p}=\frac{Z_{c w} \cdot h_{c w}}{\left(Z_{c w} \cdot h_{c w}+Z_{c s d} \cdot h_{c s d}\right)} \\
& Z_{c w}=\frac{1}{H c w} \cdot Z_{c e d}=\frac{k o c \cdot M s d \cdot \rho_{n d}}{H e n}, \\
& H e n=\frac{V_{p}}{(W s / M w)} \\
& f r_{p}=k w_{p} \cdot S_{p} \cdot\left(\bar{q}_{a l}+q_{w}\right) \\
& \frac{d S_{p}}{d t}=f_{p} \cdot x_{m p}^{i n i}-f r_{p}-K_{p} \cdot S_{p}, \\
& K_{p}=1.047^{\theta b-20} \theta d k_{w}
\end{aligned}
$$


ただし, $f_{p}$ : 点源排水の質量配分率, $x_{m p}$ : 地先排出量 (農薬以外) $\left(\mathrm{mg} \mathrm{s}^{-1}\right), Z$ : フガシティー容量 $\left(\mathrm{Pa}^{-1} \mathrm{~m}^{-3}\right.$ $\mathrm{mol}), h:$ 水路での容積分率, Hen : ヘンリー定数 $(\mathrm{Pa}$ $\left.\mathrm{m}^{3} \mathrm{~mol}^{-1}\right), c w$ : 流達過程を想定した水路 (水路水)を 表す添字, $V_{p}$ : 蒸気圧 $(\mathrm{Pa}), M w$ : 分子量 $\left(\mathrm{g} \mathrm{mol}^{-1}\right), W_{s}$ : 水溶解度 $\left(\mathrm{g} \mathrm{m}^{-3}\right), c s d$ : 堆積掃流過程を想定した水路 (水路浮泥)を表す添字, $\rho_{s d}$ : の密度 $\left(\mathrm{g} \mathrm{m}^{-3}\right), f r_{p}$ : 点 源排水に伴う排出物質の流達負荷量 $\left(\mathrm{mg} \mathrm{s}^{-1}\right), S_{p}$ : 残 存負荷量 $(\mathrm{mg}), k w_{p}$ : 掃流係数 $\left(\mathrm{m}^{-3}\right)$, とする.

水路における堆積掃流過程は, 点源排水により流 達しえない物質（吸着や沈降による堆積）と出水時 に土壤A層から供給される物質を対象に, 堆積・掃 流を表現する。すなわち，

$$
\begin{aligned}
& f r_{n p}=k w_{n p} \cdot S_{n p} \cdot \frac{\bar{q}_{a l}}{A}
\end{aligned}
$$

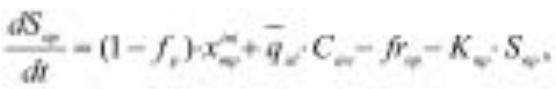

$$
\begin{aligned}
& K_{\psi}=1.047^{\alpha-3} \mathrm{ax} \text {, }
\end{aligned}
$$

ここに, $f r_{n p}$ : 流達負荷量 $\left(\mathrm{mg} \mathrm{s}^{-1}\right), S_{n p}$ : 堆積負荷量 $(\mathrm{mg}), k w_{n p}$ : 掃流係数 $\left(\mathrm{m}^{-1}\right)$, である. 掃流係数は, 出 水のない晴天時を想定し, $d$ を相当時間数 ( $\mathrm{s}$ ), 残存負 荷量の飽和値 $S_{p 0}$ を投入する負荷量 $f_{p} x_{m p}{ }^{i n i}$ の相当時間 数dの残存分であると仮定し, 次式より算定する.

$$
k w_{p} \cdot S_{p 0} \cdot q_{w}=f_{p} \cdot x_{m p}^{i n i}, \quad k w_{p}=\frac{1}{q_{w} \cdot d}
$$

\section{3）河道における物質動態}

移流拡散過程に加え, 沈降や再浮上, 微生物によ る生分解, などを考慮すると, 物質動態の収支式は 以下のように表現される.

$$
\begin{aligned}
& \frac{\partial}{\partial r}\left(A, C r_{*}\right)+\frac{\partial}{\partial x}\left(A_{r} U r C r_{*}\right)=\frac{\partial}{\partial x}\left(A, D r \frac{\partial C r_{z}}{\partial x}\right) \\
& +W r \frac{A_{r}}{H r}+G r \frac{A_{f}}{R}+D_{s+1}-K_{*} A_{r} C r_{*}+f r
\end{aligned}
$$

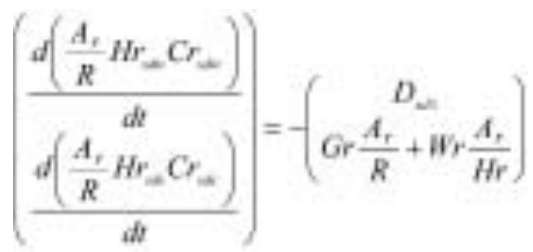

$$
\begin{aligned}
& +\left(\begin{array}{c}
D_{-3} \\
-D_{\omega}
\end{array}\right)-\left(\begin{array}{l}
K_{-} \frac{A}{R} H r_{-} C r_{-} \\
K_{-} \frac{A_{+}}{R} H r_{-\infty} C r_{-}
\end{array}\right)
\end{aligned}
$$

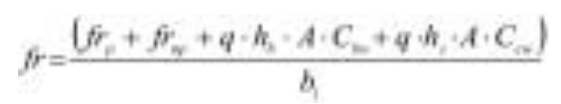

で求められる。ここに, $C_{r}$ : 濃度 $\left(\mathrm{mg} \mathrm{m}^{-3}\right), f r$ : 斜面か ら河道への流入負荷量 $\left(\mathrm{mg} \mathrm{m}^{-1} \mathrm{~s}^{-1}\right), K$ : 分解速度定 数 $\left(\mathrm{s}^{-1}\right), s d w$ : 河川浮泥液相を表す添字, $s d s$ : 河川浮泥 固相を表す添字, $D_{s d l}$ : 河川水と河川浮泥液相との拡 散移動量 $\left(\mathrm{mg} \mathrm{m}^{-1} \mathrm{~s}^{-1}\right), D_{s d 2}$ : 河川浮泥における液相と 固相間の拡散移動量 $\left(\mathrm{mg} \mathrm{m}^{-1} \mathrm{~s}^{-1}\right)$, を表す.

\section{2. 生態系評価モデル \\ 1) PBPKモデルの導入}

流域に生息する魚類の体内にどれほど化学物質が 蓄積するのかを推定するためにPBPK (Physiologically Based Pharmacokinetic Model) (Nichols et al..$^{5}$, 1990) モデルを導入する. 基礎式として,

$$
\begin{aligned}
& d A_{i} / d t=Q_{i}\left(C_{a r t}-C_{v i}\right) \\
& C_{i}=A_{i} / V_{i} \\
& C_{v i}=C_{i} / P_{i}
\end{aligned}
$$

を用いる.ここに, $A_{i}$ : コンパートメント中の化学物質の 総量 $(\mu \mathrm{g}), Q_{i}$ : コンパートメントへ流入する動脈 (liters/hour), $C_{a r t}$ : 動脈での血中化学物質濃度 $(\mu$ $\mathrm{g} /$ liter),$C_{v i}$ : コンパートメントでの血中化学物質濃度 ( $\mu \mathrm{g} /$ liter $), C_{i}$ : コンパートメント中での化学物質濃度 ( $\mu \mathrm{g} /$ liter $), \mathrm{V}_{\mathrm{i}}$ : コンパートメントの体積 (liters), $P_{i}$ : 臓 器と血液の分配係数 $(\mu \mathrm{g} /$ liter in tissue $/ \mu \mathrm{g} /$ liter in blood), である.

図ー3に示すように魚類の体内をモデル化するに 際して, 化学物質の摂取経路としてエラからの摂取 を考慮し、コンパートメントは呼吸量・心臟・腎 臓・肝臓・脂肪組織・血流量の少ない組織・血流量 の多い組織の7つを考慮する。

すなわち， エラ組織 (Fish gill description) :

$Q_{w} \leq Q_{c} \cdot P_{b w}$ のとき

$$
F_{s}=Q_{w}\left(C_{\text {vop }}-\frac{C_{\text {ing }}}{P_{b w}}\right)
$$

$Q_{w}>Q_{c} \cdot P_{b w}$ のとき

$$
F_{\mathrm{g}}=Q_{c} \cdot P_{\text {hwo }}\left(C_{\text {weyp }}-\frac{C_{\text {tess }}}{P_{\text {ber }}}\right)
$$




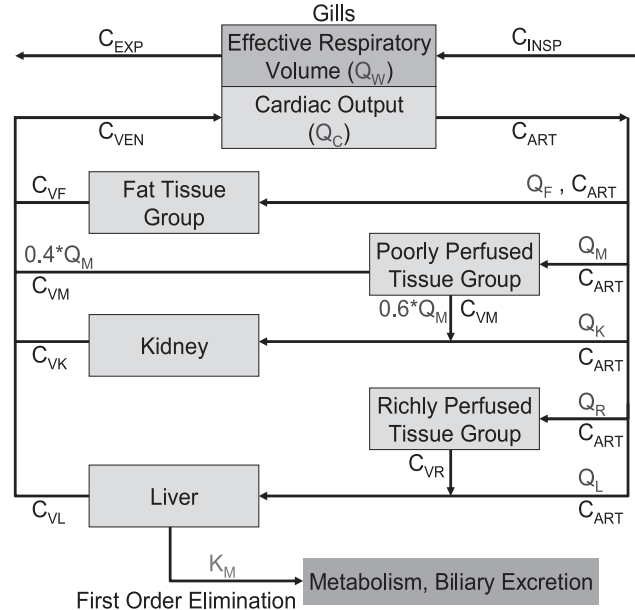

図-3 生態(魚)内での毒性化学物質の動態

Fig.3 Modeling of toxic-chemical dynamics in the fish. (Nichols et al. ${ }^{5)}$, 1990)

血中化学物質濃度（Concentration in blood）：

$$
F_{g}=Q_{c}\left(C_{a r t}-C_{v e n}\right), \quad C_{a r t}=C_{v e n}+\frac{F_{g}}{Q_{c}}
$$

血流量の多い組織（Richly perfused tissue group）:

$$
V_{r} \frac{d C_{r}}{d t}=Q_{r}\left(C_{a r t}-C_{v r}\right), \quad C_{v r}=C_{i} / P_{i}
$$

血流量の少ない組織（Poorly perfused tissue group）：

$$
V_{m} \frac{d C_{m}}{d t}=Q_{m}\left(C_{a r t}-C_{v m}\right), \quad C_{v m}=C_{m} / P_{m}
$$

腎臓（Kidney）:

$$
\begin{aligned}
V_{k} \frac{d C_{k}}{d t}= & Q_{k} \cdot C_{a r t}+0.6 Q_{m} \cdot C_{v m} \\
& -\left(Q_{l}+0.6 Q_{m}\right) C_{v k}, \quad C_{v k}=C_{k} / P_{k}
\end{aligned}
$$

脂肪組織（Fat tissue group）：

$$
V_{f} \frac{d C_{f}}{d t}=Q_{f}\left(C_{a r t}-C_{v r}\right), \quad C_{v f}=C_{f} / P_{f}
$$

肝臓 (Liver) :

$$
\begin{gathered}
V_{l} \frac{d C_{l}}{d t}=Q_{l} \cdot C_{a r t}+Q_{r} \cdot C_{v r}-\left(Q_{l}+Q_{r}\right) C_{v l} \\
\quad-K \cdot C_{v l} \cdot V_{l}, \quad C_{v l}=C_{l} / P_{l}
\end{gathered}
$$

静脈（Mixed venous blood）:

$$
Q_{c} \cdot C_{\mathrm{vev}}=Q_{f} \cdot C_{i g}+0.4 Q_{n} \cdot C_{n+v}+\left(0.6 Q_{n}+Q_{k}\right)
$$

ここに, $l$ : 肝臓コンパートメント, $f$ : 脂肪組織コンパー
トメント, $m$ : 血流量の少ない組織のコンパートメント, $r$ : 血流量の多い組織のコンパートメント, $k$ : 腎臟コン パートメント, $Q_{w}$ : 有効呼吸気量 (liters water $/ \mathrm{hr}$ ), $Q_{c}$ : 心臓からの血流量 (liters blood $/ \mathrm{hr}), P_{b w}$ : 血液と水の 分配係数 $(\mu \mathrm{g} /$ liter in blood $/ \mu \mathrm{g} /$ liter in water $), C_{\text {inss }}$ : エラに取り込まれた水中の化学物質濃度 $(\mu \mathrm{g} / \mathrm{liter})$, $C_{v e n}$ : 静脈中の化学物質濃度 $(\mu \mathrm{g} /$ liter $), F_{g}$ : エラでの 化学物質フラックス $(\mu \mathrm{g} / \mathrm{hr}), K_{m}$ : 分解係数 $(1 / \mathrm{hr})$, である。

\section{2）複数化学物質に対するリスク評価手法}

流域における化学物質リスク算定のために, 複数 の化学物質を評価対象とする。ここで，排出源物質 の排出量, 物性情報等に関するデー夕収集の容易性 から，ノニルフェノールとLASを毒性化学物質動態 モデルによる推計を実施する。それ以外の物質は以 下に示す方法により推計する。

化学物質混合物の毒性を考慮する際に用いられる 手法は，類似した化学物質をグループに分ける手法， 数種類の既知の化合物に着目しその他の物質を媒体 として取り扱う手法の 2 種類があり (Robinsona $e t$ $\left.a l .{ }^{6)}, 2004\right)$, 本研究では, 前者を用いる. 対象化学

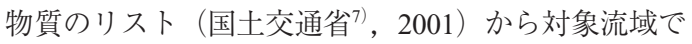
観測された物質群のうち, KocおよびPNEC (Predicted No-Effect Concentration）が得られるものを抽出し， Kocを用いてノニルフェノールに近いグループとLAS に近いグループに分ける。それぞれのグループにつ いて, 水質モデルから得られた化学物質の分布を利用 し，観測濃度の比から分布を推定する。式で示すと，

$$
\frac{C_{a}}{C_{b}}=\frac{C_{a_{-} o b}}{C_{b_{-} o b}}
$$

となる.ここに, $C_{a}$ : 対象化学物質の推定濃度 $(\mu \mathrm{g} / \mathrm{L})$, $C_{a \_o b}$ : 対象化学物質の観測濃度 $(\mu \mathrm{g} / \mathrm{L}), C_{b}:$ ノル フェノールまたはLASの推定濃度 $(\mu \mathrm{g} / \mathrm{L}), C_{b \_o b}$ :ノニ ルフェノールまたはLASの観測濃度 $(\mu \mathrm{g} / \mathrm{L})$ ，である。

PBPKモデルでは体内での化学物質濃度を計算する ため, 体内での化学物質動態が化学物質ごとに異な るが，ノニルフェノールを代表值として取り扱う。

$$
C_{r Q, W}=\sum_{x} C_{x}-R p_{x}=\sum_{x} C_{x} \frac{P_{N P}}{P_{x}}
$$

ここに, $C_{E Q, N P}$ : 混合物全体をノニルフェノールに換算 した濃度 $(\mu \mathrm{g} / \mathrm{L}), x$ : 対象化学物質, $C_{x}$ : 化合物 $x$ の 濃度 $(\mu \mathrm{g} / \mathrm{L}), R p$ : 相対毒性強度 (Relative Potency), である. 有害化学物質の水生生物に対するリスク評価 
手法としては, 生態毒性試験の結果より求めたPNECと モデル等によって推定したPEC (Predicted Environment Concentration)を用いてPEC/PNECを計算する手法が 一般的である.ここでは, 環境中濃度ではなく魚類の体 内での濃度を用い

$$
R_{x}=\frac{C_{x_{-} f i s h}}{C_{P N E C_{-} x_{-} f i s h}}
$$

と考える。ここに， $R_{x}$ : 化合物 $\mathrm{x}$ のリスク， $C_{x_{-} \text {fish }}$ : 化合物 $\mathrm{x}$ の予測魚類体内濃度, PNEC: 予測無影響濃度 (Predicted No-Effect Concentration) $(\mu \mathrm{g} / 1), C_{P N E C x_{-} f i s h}$ : 化合物 $x$ の予測無影響魚類体内濃度であり, 対象生物 に対する化学物質リスクRは

$$
R=\sum_{x} R_{x}
$$

となる。

\section{IV 。適用と考察}

\section{1. 流域のモデル化とデータ整備}

対象流域として琵琶湖・淀川流域を選ぶ。同流域 は, 三重・滋賀 ·京都 · 大阪 $\cdot$ 兵庫 ·奈良の2府4県 にまたがる流域面積 $8,240 \mathrm{~km}^{2}$, 幹川流路延長 $75.1 \mathrm{~km} に$ 及ぶ日本を代表する流域である。流域平 面を $1 \mathrm{~km}$ 四方のメッシュ状に分割し，鉛直方向には $\mathrm{A}$ 層からD層の4層に分割する。ここで，A層からC 層の水平流出量は河川に流出し, D層は河川流量に は影響を及ぼさない地下水層とする。また，都市か らの排水は分流式下水道を想定し, 污水を下水道普 及率に応じて下水処理場に, 下水処理場で処理され ない污水は浄化槽を経て流域に排出されるとする. 淀川流域の落水線網は図一4のようになる。

自然由来の降雨流出過程についてはAMeDASの デー夕を用い，人為起因の流出成分，すなわち 排 水量の推計には原単位法を用いる。ここで，生活排 水抢よび都市排水は夜間人口Pnの活動から発生す るとし，観光排水は都市活動排水に含まれるものと して設定する。すなわち，

$$
\begin{aligned}
& Q_{p n}=P_{n} \times D_{p n} \\
& Q_{p d}=Q_{p n} \times Q_{r d e} \\
& Q_{i s}=S \times D_{i s}
\end{aligned}
$$

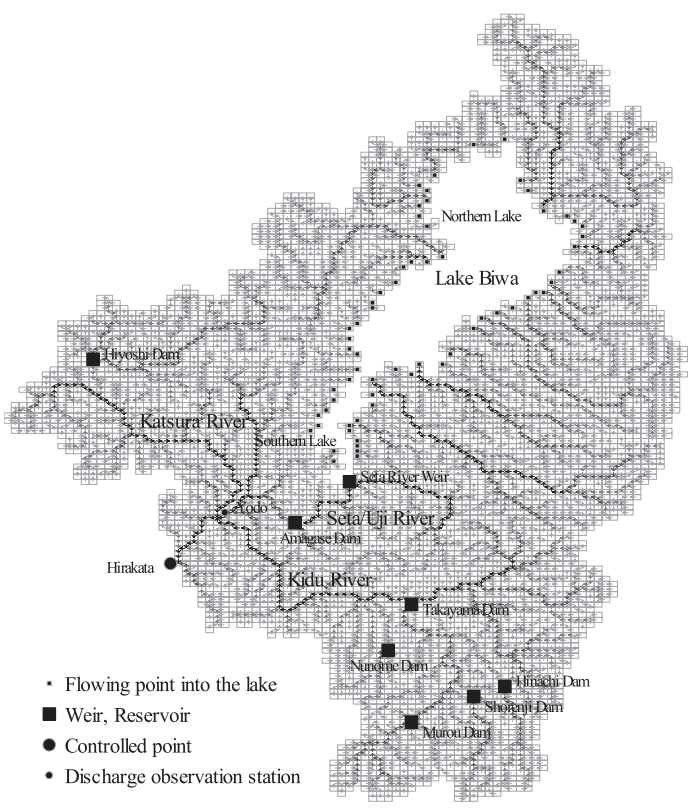

図-4 対象流域 (下流端は淀川・枚方地点)での落水線

Fig.4 Flow direction network in the Yodo River Basin.

$$
\begin{aligned}
D_{p n} & =300 \\
Q_{r d e} & =0.35
\end{aligned}
$$

ここに, $Q_{p n}$ : 生活排水量 $(1 /$ day $), Q_{p d}$ : 都市排水量 $(1 /$ day $), Q_{i s}$ : 事業場排水量 $(1 /$ day $), P_{n}$ : 夜間人口 (人), $D_{p n}$ : 生活排水原単位 ( $1 /$ day/人), $Q_{\text {rate }}$ : 都市排 水率, $S$ : 産業中分類別工業出荷額 (円), $D_{i s}$ : 事業場 排水原単位 $(1 /$ day/円), である.

化学物質は使用形態によって, 点源もしくは面源 から環境中に排出される。ここでは，全国PRTR届 出排出量に基づき化学物質排出量を推計する。 下水 道への移動量は複数の下水処理場がある場合, 下水 処理場からの晴天時放流量により比例配分する.

流域内には, 琵琶湖および7つのダム貯水池が存 在する. 本研究で対象とする化学物質濃度は, これ らの水域で観測值が定量下限值であることから，そ の動態については解析対象外とする。これらダム貯 水池の放流施設からの放流量は日平均值を, 放流水 質のうち, SS と水温は月平均值を, 毒性化学物質 は定量下限值を与えた。表一1に, 流出モデル, 水 質モデル, 毒性化学物質動態モデルに関して, 本研 究で適用したモデル定数を示す。 
表-1＼cjkstart流域モデルのモデル定数一覧

Table 1 River basin parameters for Hydro-BEAM.

\begin{tabular}{|c|c|c|c|c|c|}
\hline \multirow{20}{*}{$\frac{\text { Model }}{\text { Run-off analysis model }}$} & \multicolumn{3}{|c|}{ Parameter } & Value & Unit \\
\hline & \multirow[t]{3}{*}{$f_{A}$} & \multirow[t]{3}{*}{ Runoff coefficient } & Field & 0.210 & - \\
\hline & & & Forest & 0.300 & - \\
\hline & & & Urban area & 0.737 & - \\
\hline & \multirow[t]{4}{*}{$n$} & \multirow{4}{*}{ Roughness coefficient } & Field & 0.300 & - \\
\hline & & & Forest & 0.700 & - \\
\hline & & & Urban area & 0.030 & - \\
\hline & & & River channel & 0.035 & - \\
\hline & $k$ & \multirow{4}{*}{$\begin{array}{l}\text { Permeability coefficient } \\
\text { Effective porosity } \\
\text { Layer height }\end{array}$} & & $1.125 \mathrm{E}-05$ & $1 /$ day \\
\hline & $\lambda$ & & $\mathrm{A}, \mathrm{B}, \mathrm{C}, \mathrm{D}$-layer & $0.1-$ & - \\
\hline & \multirow[t]{4}{*}{$D$} & & A-layer & $0.3-$ & $\mathrm{m}$ \\
\hline & & & B-layer & $1.0-$ & $\mathrm{m}$ \\
\hline & & & C-layer & $2.5-$ & $\mathrm{m}$ \\
\hline & & \multirow{4}{*}{ Runoff coefficient } & D-layer & $10.0-$ & $\mathrm{m}$ \\
\hline & \multirow[t]{3}{*}{$k h$} & & B-layer & $0.03126-$ & $1 /$ day \\
\hline & & & C-layer & $0.00652-$ & $1 /$ day \\
\hline & & & D-layer & $0.00391-$ & 1/day \\
\hline & \multirow[t]{3}{*}{$k v$} & \multirow[t]{3}{*}{ Infiltration coefficient } & B-layer & $0.10552-$ & $1 /$ day \\
\hline & & & C-layer & 0.01269 & $1 /$ day \\
\hline & & & D-layer & $0.00000-$ & $1 /$ day \\
\hline \multirow{21}{*}{$\begin{array}{l}\text { Exposure concentration } \\
\text { analysis model }\end{array}$} & \multirow[t]{3}{*}{$V_{p}$} & NPnEO & & 4.14E-12- & $\mathrm{pa}$ \\
\hline & & NP & & 2.72E-01- & pa \\
\hline & & LAS & & $3.05 \mathrm{E}-13-$ & $\mathrm{pa}$ \\
\hline & \multirow[t]{3}{*}{$M_{w}$} & NPnEO & & $6.60 \mathrm{E}+02-$ & $\mathrm{g} / \mathrm{mol}$ \\
\hline & & NP & & $2.20 \mathrm{E}+02-$ & $\mathrm{g} / \mathrm{mol}$ \\
\hline & & LAS & & $3.48 \mathrm{E}+02-$ & $\mathrm{g} / \mathrm{mol}$ \\
\hline & \multirow[t]{3}{*}{$W_{s}$} & NPnEO & & $9.48 \mathrm{E}+00-$ & $\mathrm{g} / \mathrm{m}^{3}$ \\
\hline & & NP & & $5.43 \mathrm{E}+00-$ & $\mathrm{g} / \mathrm{m}^{3}$ \\
\hline & & LAS & & $2.00 \mathrm{E}+05-$ & $\mathrm{g} / \mathrm{m}^{3}$ \\
\hline & \multirow[t]{3}{*}{$k o c$} & NPnEO & & $4.63 \mathrm{E}+02-$ & $1 / \mathrm{kg}$ \\
\hline & & NP & & $6.51 \mathrm{E}+03-$ & $1 / \mathrm{kg}$ \\
\hline & & LAS & & $2.78 \mathrm{E}+02-$ & $1 / \mathrm{kg}$ \\
\hline & \multirow[t]{9}{*}{ Half lives } & NPnEO & Surface water & $8.48-$ & day \\
\hline & & & Sediment & $5.03-$ & day \\
\hline & & & Soil & $0.75-$ & day \\
\hline & & NP & Surface water & $46.30-$ & day \\
\hline & & & Sediment & $16.45-$ & day \\
\hline & & & Soil & $22.00-$ & day \\
\hline & & LAS & Surface water & $46.30-$ & day \\
\hline & & & Sediment & $16.45-$ & day \\
\hline & & & Soil & $14.00-$ & day \\
\hline
\end{tabular}




\section{2. 流出モデルの適用結果}

図一5，6に各流量観測地点に扮ける流量の計算 結果を示す.淀や枚方などの淀川下流域においては, 観測值と計算值の誤差が少ないことが見てとれる.

\section{3. 水質モデルの適用結果}

図一7に枚方でのSS濃度を示す。図より河川水中 濃度は流量に比例して増減することがみてとれる。

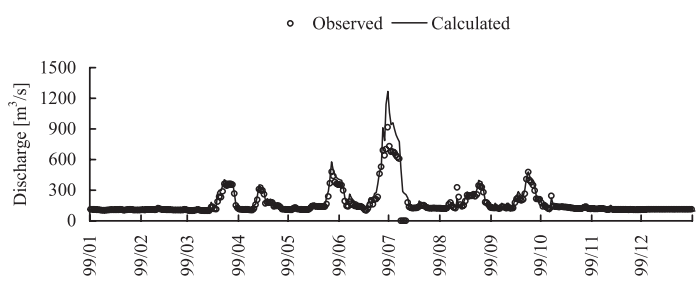

図 -5 淀地点でのハイドログラフ

Fig.5 Hydrograph at Yodo.

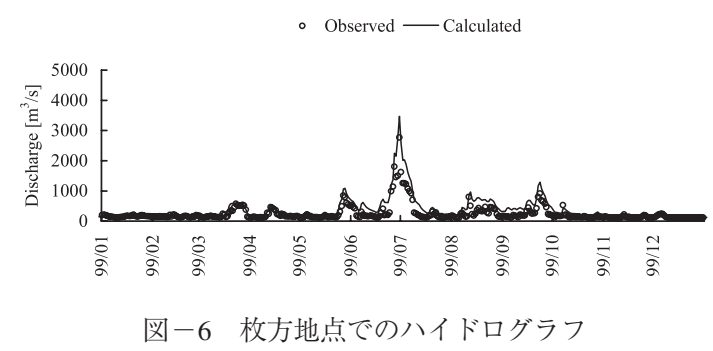

Fig.6 Hydrograph at Hirakata.

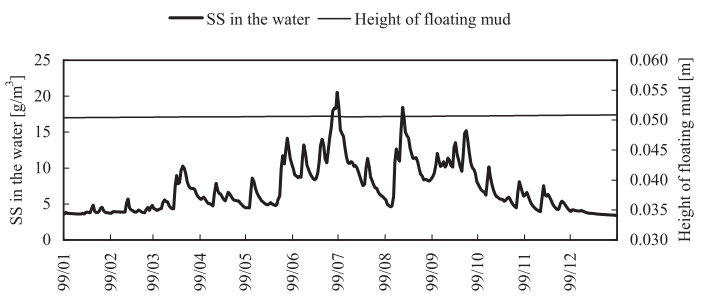

図-7 枚方地点での河川水中のSS濃度と浮泥層厚

Fig.7 Concentration of SS in the river water and floating mud at Hirakata.

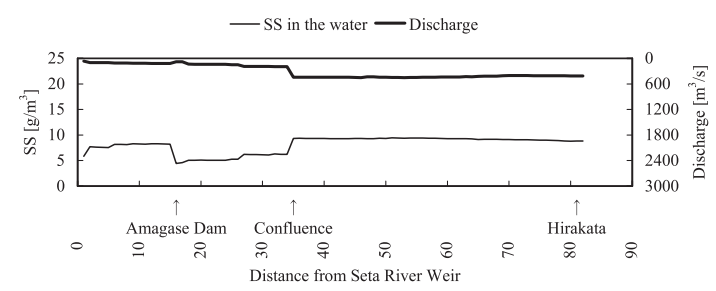

図 -8 河川縦断方向（瀬田洗堰, 枚方間）でのSS濃度

Fig.8 Concentration profile of SS in the river water.
また，河川浮泥の厚みは，ほぼ，一定であった。 図一8に瀬田洗堰・枚方間でのSS 75 \%濃度時の河 川縦断分布を示す。これより, SS濃度が流量に比 例している様子がわかる，図一9に枚方での水温の 計算結果を示す。眓より水温は気温に類似した変動 を示すことがわかる。図－10に瀬田洗堰・枚方間 での水温 $75 \%$ 值の河川縦断分布を示す. 水温は河 道内に拈いては，ほぼ一定であることが推定される。

\section{4. 毒性化学物質動態モデルの適用結果 \\ 1) LAS}

図ー11に毒性化学物質動態モデルをLASに適用し た結果を示す。これより, 夏場に流量が増えて濃度 が希釈され，また，水温が上がることによって分解 が促進された結果, 濃度が下がることがわかる。図一 12 は瀬田洗堰・枚方間でのLASの75\%值の河川縦断 分布で, 木津川, 宇治川, 桂川の三川合流後（約

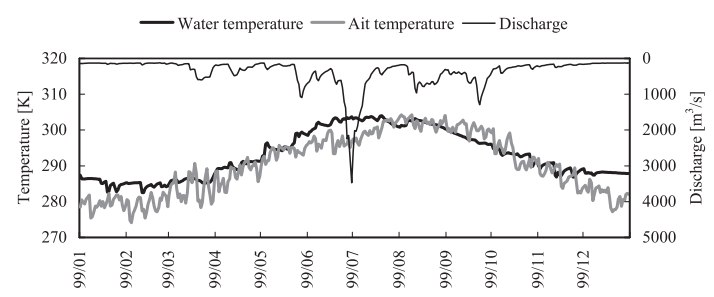

図-9 枚方地点での水温の計算值

Fig.9 Calculated water temperature at Hirakata.

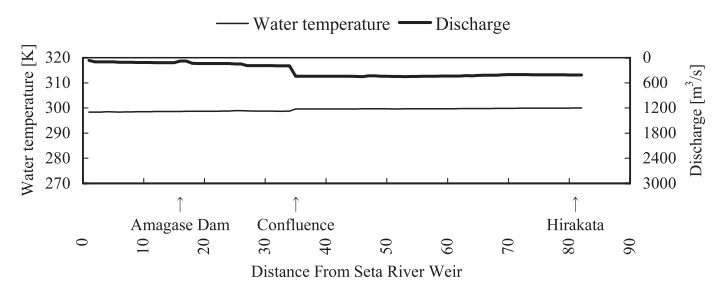

図-10 河川縦断方向での水温分布

Fig.10 Water temperature profile.

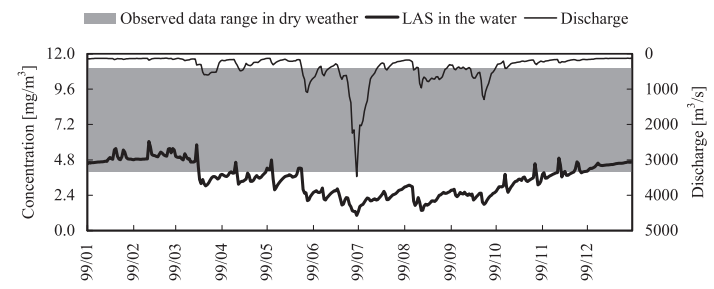

図-11 枚方地点での河川水LAS濃度の検証

Fig.11 Comparison of calculated concentration of LAS with observed data in the river water at Hirakata. 
$35 \mathrm{~km}$ 地点）では河川水濃度が流下距離に応じて顕著 に減少しており，希釈効果が働いているといえる。

図ー13に濃度の空間分布を示す。ここで，夏場 には流域全体で濃度の減少が起こっていることがわ かる，夏場には流量が増加することによる希釈効果 に加えて，水温が高くなるため分解が進みやすくな るためであると考えられる。また，河川下流部に， 高濃度地域ができていることがわかる。

2) ノニルフェノール

ノニルフェノールの解析においては，2段階の分 解過程を考慮するため, 排出源物質であるノニル フェノールエトキシレート (NPnEO) とその分解 代謝物であるノニルフェノール（NP）の計算結果 を示す。排出段階では，ノニルフェノールエトキ

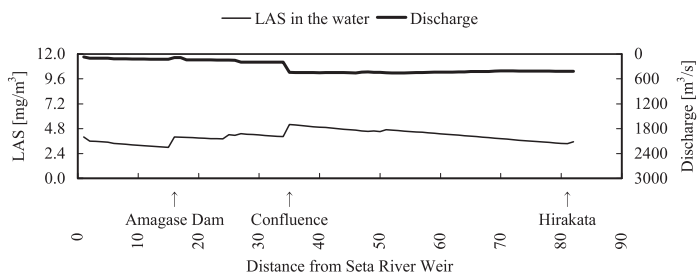

図-12 河川縦断方向での水中LAS濃度

Fig.12 Concentration profile of LAS in the river.
シレートの形で排出され，環境中で分解されてノ ニルフェノールになり，さらに分解が進めば無機化 されると設定する。

図－14，15は，ノニルフェノールとノニルフェ

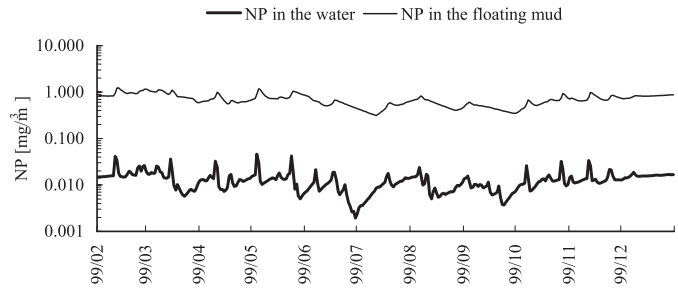

図-14 枚方地点での河川水と浮泥のノニルフェノール濃度

Fig.14 Concentration of Nonylphenol in the river water and bottom at Hirakata.

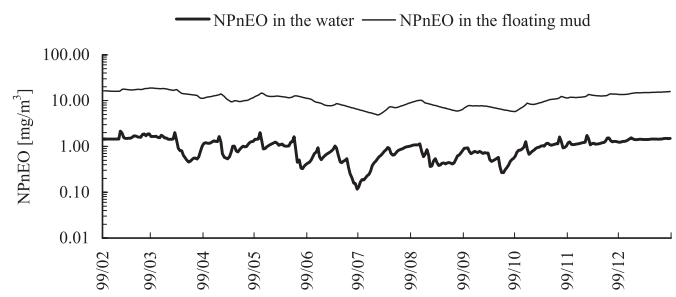

図-15 枚方地点での河川水と浮泥のノニルフェノール エトキシレート濃度

Fig.15 Concentration of Nonylphenol Ethoxylate in the river water and bottom at Hirakata.

LAS

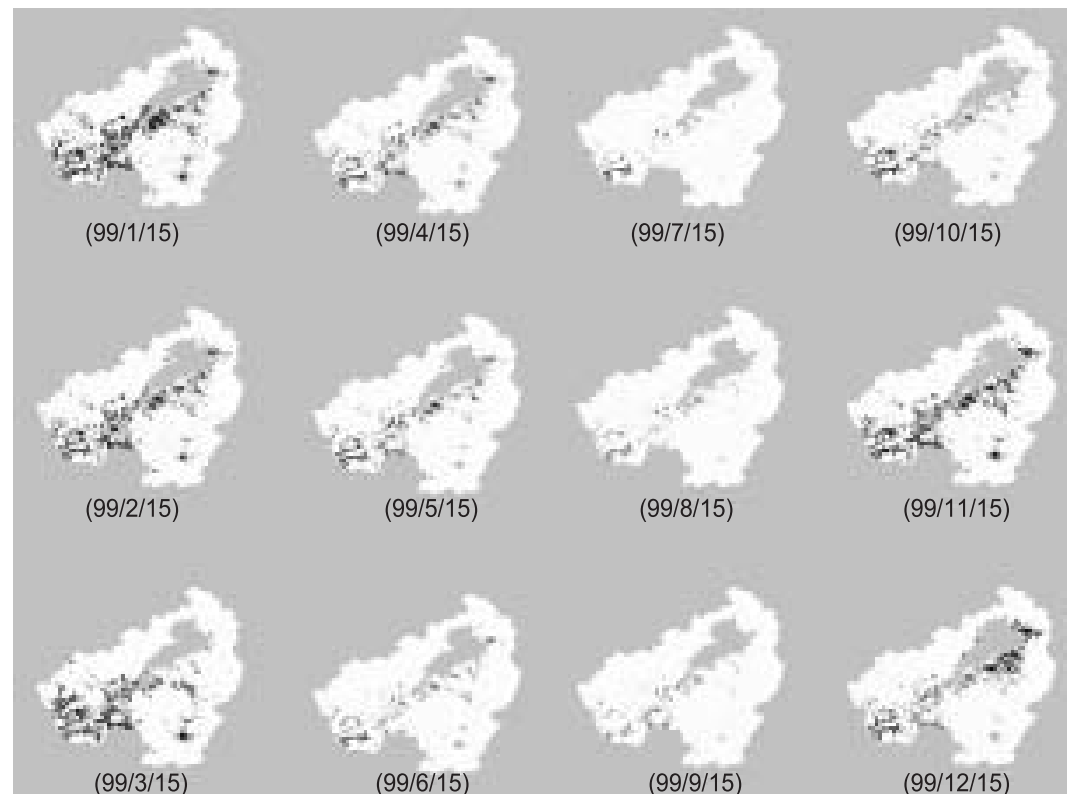

図 -13 河川水のLAS濃度分布

Fig.13 Spatial distribution of LAS concentration in the water. 
ノールエトキシレートの枚方地点での推定結果であ る. 物性に関して, ノニルフェノールとノニルフェ ノールエトキシレートではその違いが大きく2つあ る.一つは水溶性に関して後者の方が高いこと, も う一つは分解速度に関して後者の方が大きいことで ある. 従って, 排出源物質であるノニルフェノール エトキシレートは希釈効果や分解の効果を受けやす い. すなわち，季節の周期的な影響を受けやすく， 夏季には濃度が低下して冬季には濃度が高くなるこ とを示唆しており, このことは, 濃度が流量に反比 例していることで確認できる。一方, 排出源物質の ノニルフェノールエトキシレートの分解代謝物であ るノニルフェノールは分解速度が小さくKocが大き いことから，晴天時にはSSに吸着して河川水から 河川浮泥に沈降し, 河川浮泥に蓄積するため, 流れ が緩やかになる下流域になると, 河川浮泥と河川水 の間で物質の拡散移動に伴い, 河川水濃度も高くな ることが示唆される. また, 出水時には河川浮泥か らの再浮上により河川水に物質が再回帰して, 河川 水濃度が高くなることが確認できる。

図ー16はノニルフェノール濃度の計算值と観測 值との比較結果を示したものである。なお，十分な 観測值が得られなかったため観測值（国土交通省 ${ }^{7)}$, 2001, 日本石鹸洗剤工業会8)，2000）はグレーゾー ンとして，その対象期間内の最小值から最大值の範

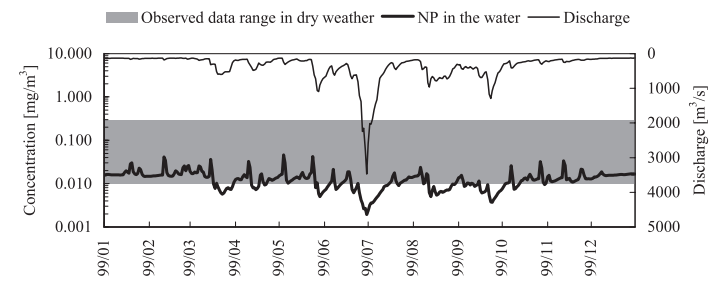

図-16 枚方地点における河川水のノニルフェノールの 計算值と観測值の比較

Fig.16 Comparison of calculated concentration of Nonylphenol with observed data in the river water at Hirakata.

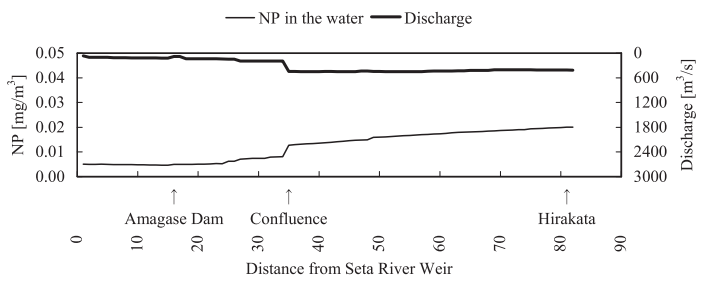

図-17 河川縦断方向でのノニルフェノール濃度

Fig.17 Concentration profile of Nonylphnol in the river water.
囲を示す．観測が晴天時を主体に行ったものである ことを考えると, 計算值の再現性は, 十分信頼性が あるといえる。図ー17に，瀬田洗堰・枚方間での ノニルフェノール $75 \%$ 值の河川縦断分布を示す. 図より流下距離に比例して濃度が上昇していること がわかる。これは，ノニルフェノールの分解速度が 遅く希釈効果が十分に働かないこと, および, 上流 から下流に移流したノニルフェノールでは流れが穏 やかになる下流域で河川浮泥に沈降し, その後河川 水へ拡散移動することを考えると, 下流域において 蓄積されることになる。このことは, 河川下流部, つまり人口密度の高い地域において高濃度になって いることからも確認できる。

\section{5. 生態評価モデルの適用結果}

表一2に化学物質の分類結果を示す. 図ー18に枚 方地点での魚類の肝臓中での化学物質濃度を示した ものである。ここで, C (PNEC) とC (EQ,NP) は対 象物質群の予測無影響濃度と濃度を, それぞれノニ ルフェノールに換算した濃度を曝露させたときの魚 類の肝臓中での物質濃度を示す。

表一3は，PBPKモデルのモデル定数を示したもの である。ここで，モデル定数は魚類（ニジマス）の 腎臓内濃度の半減期が約1日（Lewis et al. ${ }^{18)}, 1996$ )

\section{表-2 毒性化学物質の特性}

Table 2 Classified results of considered toxic-chemicals.

\begin{tabular}{|c|c|c|c|}
\hline $\begin{array}{c}\text { Toxic } \\
\text {-chemicals }\end{array}$ & $\begin{array}{c}\text { Observed data } \\
\mathrm{mg} / \mathrm{m}^{3}\end{array}$ & $\begin{array}{l}\text { PNEC } \\
\mathrm{mg} / \mathrm{m}^{3}\end{array}$ & $\begin{array}{l}\text { Kocl } \\
/ \mathrm{kg}\end{array}$ \\
\hline NP & $0.278 \quad 7)$ & $2.1012)$ & $6510.00 \quad 12)$ \\
\hline 4-tert-Octylpheno & $0.0137)$ & $0.489)$ & $78124.009)$ \\
\hline IDEHA & $0.0207)$ & $6.609)$ & $48600.00 \quad 14)$ \\
\hline LAS & $5.2008)$ & $250.00 \quad 13)$ & $278.0016)$ \\
\hline Bisphenol A & $0.0537)$ & $11.0011)$ & $314.00 \quad 15)$ \\
\hline DBP & $0.2507)$ & $4.00 \quad 10)$ & 3.14 17) \\
\hline
\end{tabular}

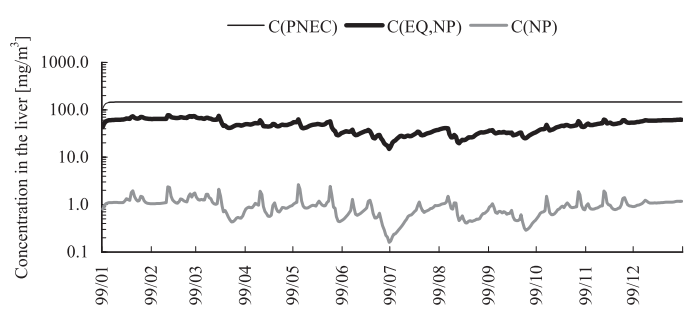

図-18 枚方地点での魚類の肝臓内における毒性化学物 質濃度

Fig.18 Concentration of toxic-chemicals in the liver at Hirakata. 
表一3 PBPKモデルのモデル定数一覧

Table 3 Parameters for PBPK model.

\begin{tabular}{l|c|c|c}
\hline \multicolumn{2}{c|}{ Parameter } & Unit & Bases \\
\hline $\mathrm{Q}_{\mathrm{w}}$ & 7.200 & liters water/hour & Nichol et al.,1990 \\
$\mathrm{Q}_{\mathrm{c}}$ & 2.070 & liters blood/hour & Nichol et al.,1990 \\
$\mathrm{Q}_{\mathrm{l}}$ & 0.060 & liters blood/hour & Nichol et al.,1990 \\
$\mathrm{Q}_{\mathrm{f}}$ & 0.176 & liters blood/hour & Nichol et al.,1990 \\
$\mathrm{Q}_{\mathrm{m}}$ & 1.242 & liters blood/hour & Nichol et al.,1990 \\
$\mathrm{Qr}_{\mathrm{k}}$ & 0.476 & liters blood/hour & Nichol et al.,1990 \\
$\mathrm{Q}_{\mathrm{k}}$ & 0.116 & liters blood/hour & Nichol et al.,1990 \\
$\mathrm{V}_{\mathrm{l}}$ & 0.013 & liters & Nichol et al.,1990 \\
$\mathrm{V}_{\mathrm{f}}$ & 0.098 & liters & Nichol et al.,1990 \\
$\mathrm{V}_{\mathrm{m}}$ & 0.818 & liters & Nichol et al.,1990 \\
$\mathrm{V}_{\mathrm{r}}$ & 0.063 & liters & Nichol et al.,1990 \\
$\mathrm{V}_{\mathrm{k}}$ & 0.008 & liters & Calibration \\
$\mathrm{P}_{\mathrm{bw}}$ & 25.000 & - & Calibration \\
$\mathrm{P}_{\mathrm{f}}$ & 40.000 & - & Calibration \\
$\mathrm{P}_{\mathrm{k}}$ & 15.000 & - & Calibration \\
$\mathrm{P}_{\mathrm{l}}$ & 2.800 & - & Calibration \\
$\mathrm{P}_{\mathrm{r}}$ & 2.800 & - & Calibration \\
$\mathrm{P}_{\mathrm{m}}$ & 3.200 & 1/hour & Calibration \\
$\mathrm{K}_{\mathrm{m}}$ & 0.010 & & \\
\hline
\end{tabular}

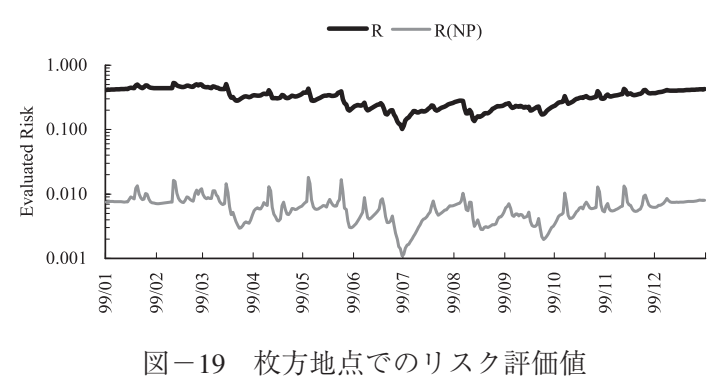

Fig.19 Evaluated risk at Hirakata.

となるようにキャリブレーションした。

図一19に枚方地点での化学物質リスク評価の結 果を示す。これより，夏場にリスクが低くなってい ることがわかる. 夏場は流量の増加による希釈や水 温上昇に伴う分解が促進される結果によるものと考 えられる。

\section{V. 結猃}

本研究では, 流域の環境評価を目的として, 琵琶 湖・淀川流域を対象にノニルフェノールとLASの動 態解析とその生態系 (魚類)への影響評価を行った。 その過程では, 熱収支解析モデル, 流出モデル, 水 質モデル, 毒性化学物質動態モデル, 生態系評価モ デルを用い，河川流域というマクロな視野から，魚
類体内の化学物質濃度というミクロな視野へと解析 を展開した。魚類体内における化学物質の蓄積濃度 に関する検証に課題が残るものの，最後に本研究の 成果をまとめると以下のようになる。

i）水量モデルでは，流域内での時間分布および空 間分布を求め，その妥当性を検証した。

ii）水質モデルでは，流域内でのLASとノニルフェ ノールの時間分布および空間分布を求め, 検証 を含めてその動態を考察した。

iii）PBPKモデルでは, 魚類体内への化学物質蓄積濃 度を求めた。

iv）複数化学物質のリスク評価では, 複数化学物質 の魚類に対するリスク評価を行った.

今後, 魚類体内における化学物質の蓄積濃度など 検証に必要なデータの収集，生物間の相互影響の考 慮, 流域における化学物質リスク評価, を行いたい。

\section{参考文献}

松井三郎・田辺伸介・森 千里・井口泰泉・吉原新一 · 有薗幸司 . 森澤眞輔 (2002)：環境ホルモンの最前線, 有斐閣選書.

Brooks, B.W. (2006) : Timothy M. Riley, Ritchie D. Taylor: Water quality of effluent-dominated ecosystems: ecotoxicological, hydrological, and management considerations, Hydrobiologia 556, pp.365-379.

東海明宏・小尻利治・吉川仁恵 (2002) : 分布型流出モデルをべー スとした生態水質モデルによる流域環境評価,第6回水資源に関 するシンポジウム論文集, pp.229-234. 
宗宮功 (1990): 自然の浄化機構, 技報堂出版.

Nichols, J.W., Mckim, J.M., Andersen, M.E., Gargas, M.L., Clewell, H.J. III, and Erickson, R.J. (1990) : A Physiologically Based Toxicokinetics Model for the Uptake and Disposition of Waterborne Organic Chemicals in Fish, Toxicology and Applied Pharmacology: Vol.106, pp.433-447.

Robinsona, P., and MacDonellb, M. ( 2004) : Priorities for mixtures health effects research, Environmental Toxicology and Pharmacology 18, pp.201-213.

国土交通省河川局 (2001): 平成13年度水環境における内分泌撹 乱物質に関する実態調査結果

日本石鹸洗剤工業会 (2000) : 環境年報Vol.25

環境省 (2003)：化学物質の環境リスク評価第2巻

環境省 (2002)：化学物質の環境リスク評価第1巻

環境省 (2004)：化学物質の環境リスク評価第3巻
（独）産業技術総合研究所 (2004)：詳細リスク評価書ノニルフェ ノール

日本石賖洗剂工業会 (2004)：界面活性剂のヒト健康影響および環 境影響に関するリスク評価

(財) 化学物質評価研究機構 (1998): 既存化学物質安全性評価 シートアジビン酸ジ-2-エチルヘキシル

(財) 化学物質評価研究機構 (1998)：既存化学物質安全性評価 シートビスフェノールA

（独）製品評価技術基盤機構 (2005): 化学物質の初期リスク評価

書＼cjkstart直鎖アルキルベンゼンスルホン酸及びその塩

（独）製品評価技術基盤機構 (2005)：化学物質の初期リスク評価

書 フタル酸ジ-n-ブチル

Lewis, S.K. and Lech, J.J. (1996) : Uptake, disposition, and persistence of nonylphenol from water in rainbow trout (Oncorhynchus mykiss). Xenobiotica, 26, 8, pp. 813-819.

(受付：2006年8月31日，受理：2006年12月4日)

\title{
River Basin Environment Assessment Considering Chemical Impact against Fish
}

\author{
Morihiro WASA ${ }^{1)}$ Tomoya KAWAGUCHI ${ }^{2)}$ Toshiharu KOJIRI ${ }^{3)}$ Akihiro TOKAI ${ }^{4)}$ \\ 1) Nippon Koei Co.,Ltd. \\ (4, Kojimachi 5chome, Chiyoda-ku, Tokyo, 102-8539, Japan) \\ 2) Nihon Suido Consultants Co., Ltd. Japan \\ (22-1, Nishi-Shinjuku 6-chome, Shinjuku-ku, Tokyo, 163-1122, Japan) \\ 3) Water Resources Research Center, DPRI, Kyoto University \\ (Gokasho, Uji, Kyoto 611-0011, Japan) \\ 4) Research Center for Chemical Risk Management, AIST \\ (16-1, Onogawa, Tsukuba, Ibaraki, 305-8569, Japan)
}

For an environment assessment related with the water pollution in the river basin, an analysis of each process such as pollutant release, distribution and exposure processes is needed to link in the significant scale. The purpose of this research is to build a hydrological river basin assessment model for an estimation of the water pollution distribution and an assessment of damage on fish population by using the distributed runoff model. A target area of the proposed simulation is the Yodo River basin including the Lake Biwa. The simulation is performed for an estimation of the distribution of Nonylphenol and Linear Alkylbenzene Sulfonate by physical-based model. Physiologically Based Pharmacokinetic model is used to estimate the accumulation of the chemical substance in fish body and the risk assessment of chemical substances is analyzed based on the simulated concentration of the chemical substances.

Key words : distributed runoff model, river basin environment, chemical substances, PBPK 